\title{
Research on Treating Acid Wastewater Containing Heavy Metals by Sulfate-Reducing Bacteria
}

\author{
CHEN Wei-ting ${ }^{1}$, ZHANG Hong-guo $^{1 *}$, LUO Ding-gui ${ }^{1}$, CHEN Yong-heng ${ }^{1}$ \\ ${ }^{1}$ School of Environmental Science and Engineering, Guangzhou University; \\ Key Laboratory for Water Quality Security and Protection in Pearl River Delta, \\ Ministry of Education and Guangdong Province; \\ Guangzhou 510006, China \\ *hgzhang@gzhu.edu.cn
}

\begin{abstract}
Biological treatment with sulfate-reducing bacteria (SRB) has been considered as the most attractive alternative for heavy-metals-containing effluents decontamination. Ordinarily, these wastewaters contain high concentrations of sulfate and heavy metals, it is extremely essential for the development of a bioremediation technology to prevent its harm. Mechanism of SRB for wastewater treatment had been introduced in the paper, together with the application of treating wastewater containing several typical heavy metals. At last, current problems in engineering application of SRB are explained in the paper.
\end{abstract}

Keywords-sulfate-reducing bacteria; mechanism; heavy metal; wastewater

\section{INTRODUCTION}

Anthropogenic release of heavy metals in the environment is principally related to effluents discharged from mine (drainage), metallurgy, electroplating, dye and other industrial activities. It contains high concentration of sulfate and a large number of soluble heavy metal ions. Receiving water will be acidic and produce potential corrosion. Heavy metals such as zinc, copper, lead and thallium, etc. can be accumulated through food chain and result in chronic poisoning which is increasingly harmful to human being and environment [1-5]. Hence, it is a significant and urgent study field about these effluents' treatments to people's health and ecology environment.

Several methods could be applied to remove heavy metals from acid wastewaters, such as chemical precipitation, ion-exchange, reverse osmosis, and electrolysis process, etc. Despite effective treatment, these methods are extravagant and generate large amounts of residual sludge. Therefore, Biological treatment, as a promising alternative over physical-chemical and other methods for heavy metals removal, is now of considerable interest due to its running costs, strong adaptability and no secondary pollution. It obtains widespread concern by the domestic and international environmental scientists [2].

Anaerobic reduction of sulfate by Sulfate-reducing bacteria (SRB) has been reported to be used for the treatment of a multitude of sulfate-containing industrial effluents. SRB are a kind of anaerobic bacteria with various nutrition types and different shapes, which can dissimilate organisms by using sulfate or other oxidation state sulfides as electron acceptors [6,7]. SRB have the capabilities to reduce sulfate to sulfide which reacts with certain metals dissolved, such as copper, iron and zinc, forming insoluble precipitates. More and more attention should be gotten for their particular dominances.

\section{SRB AND TREATMENT MECHANISM}

\section{A. Sulfate-Reducing Bacteria}

SRB can universally exist in a variety of environments such as lakes, marshes, paddy fields, petroleum deposits, underground pipelines, some industry wastewaters, and some ruminants' first stomach, etc. SRB have strong survival ability because of the enzymes that won't poisoned by oxygen-containing. SRB are included in a group of chemoorganotrophic and anaerobic bacteria, which contains representatives of the genera Desulfovibrio, Desulfomicrobium, Desulfobacter and Desulfotomaculum, among others [8]. New genus can be separated and named due to the improvements of technology. There are nearly more than 40 species, 12 genera of SRB now [9].

\section{B. Treatment Mechanism}

The mechanism of wastewater treatment by SRB involves two stages: (i) Sulfate-reducing bacteria oxidize simple organic compounds (e.g. acetate, lactate, butyrate, propionate etc.) by utilizing sulfate as an electron acceptor and generating hydrogen sulfide and bicarbonate ion under anaerobic conditions (1)), and (ii) the biologically produced hydrogen sulfide reacts with dissolved heavy metals such as $\mathrm{Cu}, \mathrm{Zn}$, and Ni to form insoluble metal sulfide precipitates (2)) [10].

$$
\begin{gathered}
2 \mathrm{CH}_{2} \mathrm{O}+\mathrm{SO}_{4}{ }^{2-} \rightarrow \mathrm{H}_{2} \mathrm{~S}+2 \mathrm{HCO}_{3}{ }^{-} \\
\mathrm{Me}^{2+}+\mathrm{H}_{2} \mathrm{~S} \rightarrow \mathrm{MeS} \downarrow+2 \mathrm{H}^{+}(\mathrm{Me}=\text { Metal }) \\
\text { III. ENGINEERING APPLICATION }
\end{gathered}
$$

Physiological and biochemical characteristics of SRB make them have great potential and application space in wastewater treatment. Some successes in wastewater containing heavy metal ions treatment has recently been achieved by SRB. And it has become a hot point and front line gambit among the field of relevant wastewater treatment.

\section{A. Chromium-Containing Wastewater}

Acidic wastewater from electroplating, tanning, mining and other industrial wastewater contains a lot of $\mathrm{SO}_{4}{ }^{2-}$. 
Chromium mainly exists in wastewater by $\mathrm{Cr}$ (III) and $\mathrm{Cr}$ (VI). $\mathrm{Cr}$ (VI) is easy to accumulate in organisms and water because of its solubility, strong oxidation, toxicity and other characteristics [4]. Chromium- containing wastewater treatment is particularly important and must be treated before discharged.

Biological treatment of $\mathrm{Cr}$ (VI) contaminated waters was performed in fixed bed reactors inoculated with SRB growing on ethanol. At steady state the column inoculated with SRB removed $65 \pm 5 \%$ of sulfate and $95 \pm 5 \%$ of chromium [11]. A new reduction-regeneration circulation process for treating chromium-containing wastewater and reclaiming chromium was developed with the regeneration character of the composites which consisted of SRB and nanosized iron sulfide produced by SRB in 2009. The results indicated that the concentration of total chromium was less than $0.929 \mathrm{mg} / \mathrm{L}$ in the effluent; $\mathrm{Cr}$ (VI) was less than $0.019 \mathrm{mg} / \mathrm{L}$ simultaneously [12]. The results of treatment of real chromium-containing wastewater by SRB in 2011 showed that the maximum removal of chromium was found to be $82.6 \%$ in chromium amended wastewater [13]. The effect of chromium-containing wastewater treatment by SRB with static test point out that when the concentration of chromium wastewater was $50 \mathrm{mg} / \mathrm{L}$ to $100 \mathrm{mg} / \mathrm{L}$, the processing efficiency could reach $99.62 \%$ and $99.74 \%$, and the best economical deal time was $1 \mathrm{~h}[14]$.

\section{B. Zinc-Containing Wastewater}

Zinc as the 'Flower of Life', is an important material to maintain body's normal growth and metabolism. It can be widely found in human muscles and bones. High levels of Zinc in the human body will inhibit the activity of phagocytic cells, bactericidal and reduce the body's immune function, thus increase the susceptibility to diseases $[15,16]$. Nowadays, some industrial projects such as bridges, roads, electricity transmission network, etc. requires a lot of galvanized steel. Therefore, they will produce a large number of zinc-containing wastewater which do harm for the environment and human health.

A process for the treatment of $\mathrm{Zn}^{2+}$ containing wastewater by SRB in an UASB reactor had been studied in 1995. When the concentration of $\mathrm{Zn}^{2+}$ in influent was $100 \mathrm{mg} / \mathrm{L}$, the reactor could be successfully operated and removed $99.63 \%$ of $\mathrm{Zn}^{2+}$. And when the HRT reduced to $6 \mathrm{~h}$, the removal rate was $94.55 \%$ [17]. In 2006, according to the research about zinc removal mechanism by sieved SRB, it indicated that the efficiency of zinc removal coincides with the amount of sulfide generated by SRB and the efficiency was about $72 \%$ [18]. Compared with the treatment efficiencies of $\mathrm{SRB}$ system and $\mathrm{SRB}+\mathrm{Fe}^{0}$ system, the acclimation period of SRB reduced more than $20 \%$ under high $\mathrm{Zn}^{2+}$ concentration by $\mathrm{SRB}+\mathrm{Fe}^{0}$ system; the inhibiting concentration of $\mathrm{Zn}^{2+}$ to SRB increased by approximately $20 \%$ by the latter system as well; the reduction velocity of sulfate was fastened apparently [19]. Samia indicated in 2007 that zinc concentrations more than 150mg/L were lethal to SRB and zinc was removed effectively by SRB to less than $5 \%$ from medium containing $150 \mathrm{mg} / \mathrm{L}$ initial zinc concentrations or less [20]. In 2012, when initial $\mathrm{Zn}^{2+}$ concentrations were in the range of 73.7 to $196.8 \mathrm{mg} / \mathrm{L}$ via anaerobic batch experiments, SRB had high cultivability. But when the concentration was $262.97 \mathrm{mg} / \mathrm{L}$, the activity of SRB significantly inhibited [21].

\section{Uranium-Containing Wastewater}

Tailings and waste rock from uranium mining and smelting is the major source of uranium-containing wastewater. It will separate out a great deal of radon and pollute the surrounding environments [22]. So the wastewater need to be treated before discharged. U (VI) can be reduced by SRB to U (IV) precipitation thus prevent the migration and proliferation of radioactive uranium [23].

When $\mathrm{pH}$ value was 8.0 , the treatment effect of uranium by $\mathrm{SRB}$ was the best. $\mathrm{Cu}^{2+}$ concentration plays an important role in the reduction of $U$ (VI) as well [24, 25]. It inhibited the removal of $U$ (VI) significantly when the concentration was $15 \mathrm{mg} / \mathrm{L}$ [23]. What's more, the U (VI) reductive precipitation would not commence until $\mathrm{NO}_{3}{ }^{-}$was completely eliminated [26]. Reduced uranium and sulfate by the coordination of SRB and zero-valent iron, the reductive rate of $\mathrm{U}(\mathrm{VI})$ could reach $99.4 \%$ [22].

\section{Copper-Containing Wastewater}

Metallurgical industries and electronics industries lead to a large number of generations of copper-containing wastewater. If excess copper is inhaled, the human digestive system will be stimulated and may lead to cirrhosis after a long-term inhalation. Lower organisms and crop will be toxic by copper and appear diseases. So it is particularly important to treat and recycle copper before discharge [27].

Kathy indicated in 2000 that copper was removed effectively by $\mathrm{SRB}$ when $\mathrm{Cu}^{2+}$ concentration was $150 \mathrm{mg} / \mathrm{L}$ or less, the removal rate of copper could reach $99 \%$. The association of copper with bacteria cells could promote precipitation rate [28]. By the laboratory intermittent experiment, it was feasible to use SRB to absorb the copper in the mine wastewater diluted. The removal rate of copper ions could reach $99.8 \%$ and $100 \%$ after operating 24d [29]. Furthermore, some experiments showed that the removal rate of copper ions were $99.9 \%$ under the conditions of $\mathrm{pH} 7$, $35^{\circ} \mathrm{C}$ and the ratio of $\mathrm{COD} / \mathrm{SO}_{4}{ }^{2-}$ at 3 [30]. On the bases of analyses of principle and applications of $\mathrm{ABR}$ and the culture and acclimatization of SRB granular sludge, the removal rate of $\mathrm{Cu}^{2+}$ became stabled over $98 \%$ while mass concentration of $\mathrm{Cu}^{2+}$ was lower than $35 \mathrm{mg} / \mathrm{L}$ [31].

\section{E. Other Metal-Ions-Containing Wastewater}

Currently, a lot of wastewater containing heavy metals is generated by the mining industries, leather industries and other industries. The contents and components of heavy metals in it are quite different. Except for the metal ions mentioned before, scientists also pay attention to other heavy metal ions, such as Fe, Mn, etc. The effect of this wastewater containing heavy metal ions treatment is significant.

Bradley proved in 1998 that SRB could exist in the solution containing $\mathrm{Cr}$ (VI), U (VI), Mn (IV) and Fe (III). And it could use these metal ions as electron acceptors ${ }^{[32]}$. 
Adding some metal ions $\mathrm{Fe}, \mathrm{Zn}$ and $\mathrm{Cu}$ which concentrations were respectively $400 \mathrm{mg} / \mathrm{L}, 150 \mathrm{mg} / \mathrm{L}$ and $80 \mathrm{mg} / \mathrm{L}$ to AMD was not toxic for the SRB presented in it [33]. What's more, SRB culture solution could effectively precipitate $\mathrm{Ni}^{2+}, \mathrm{Cu}^{2+}$ and $\mathrm{Fe}^{3+}$ while $\mathrm{Mg}^{2+}$ remain in the liquid phase [34]. When content of sulfate reduce $50 \pm 10 \%$, the metal ions such as $\mathrm{As}(\mathrm{V}), \mathrm{Cd}, \mathrm{Cr}(\mathrm{VI}), \mathrm{Cu}, \mathrm{Zn}$, etc. could be totally removed [35]. The results of the experiment that treating real wastewater containing heavy metals by SRB showed that there was no inhibition of SRB growth while the removal efficiencies of $94-100 \%$ for $\mathrm{Cu}^{2+}, \mathrm{Zn}^{2+}$, $\mathrm{Ni}^{2+}$ and $\mathrm{Cr}^{6+}$ existed in the solution [10]. In addition, the removal rate of $\mathrm{Fe}^{2+}$ and $\mathrm{Mn}^{2+}$ by $\mathrm{SRB}$ were respectively $99.37 \%$ and $59.18 \%$ and the effect was significant [36].

Comparing with the studies above, it shows that it is popular and mature to use SRB to deal with single-heavymetal-containing wastewater. But the actual wastewater contains not only a single heavy metal ion, but also a variety of heavy metal ions which may also have inhibiting effect to the physiology and biochemistry of SRB. What's more, the treatment of toxic heavy-metal-containing wastewater, such as thallium-containing wastewater, should be further studied and discussed by domestic and international scholars.

\section{CONCLUSION}

Nowadays, SRB can be widely used in wastewater treatment because of their advantages, such as simple operation, low processing cost and better treatment effect. But it still has a lot of study to do, including the following aspects:

1) The differences of contents and types of heavy metal ions will lead to differences of toxicity and inhibition of microorganisms like SRB. Single metal effect is different from multi-metals effect, which we need to conduct a comprehensive research.

2) The inhibitions or promotions between different microorganisms have yet to be study.

3) Sulfur in the wastewater can be reduced into $\mathrm{H}_{2} \mathrm{~S}$, which can strongly inhibit other microorganisms' growth, such as methanogens. Meanwhile, it can affect the survival environment and the activity of SRB. So it will change the effect of wastewater treatment by SRB. Thus, it also requires further study how to eliminate the reductive products.

4) It is very important to find the technical, feasible and inexpensive carbon source treat the wastewater containing heavy metals. We need to ensure the effluent COD reach standards while reducing processing cost.

\section{ACKNOWLEDGEMENTS}

The investigation is supported by National Natural Science Foundation (51208122); Department of Science and Technology of Guangdong Province (2010B0309 00008) and New Technological Star Project of Pearl River.

\section{REFERENCES}

[1] Fang, D., Wang, F., Shan, H. X., et al. Bio-precipitation of heavy metals from a synthetic acidic wastewater by sulfate-reducing bacteria in a bench scale continuous-flow stirred tank reactor.
Ecology and Environmental Sciences, Vol.19, No.3, 2010, pp. 562-565.

[2] Ma, C. H., \&Hu, H, Q., Research of wastewater containing heavy metals by sulfate-reducing bacteria. Science and Technology Innovation Herald, No.20, 2010, pp. 5-6.

[3] Wu, W. F., Liu, B., Li, H. J., et al. Effect of pH and salinity on sulfate reduction by microorganism. Chinese Journal of Environmental Engineering, Vol.5, No.11, 2011, pp. 2527-2531.

[4] Li, C., Wang, X. B., \& An, W. H., Application of sulfate reducing bacteria in chromium-containing wastewater treatment. Westleather, Vol.34, No.2, 2012, pp. 28-31.

[5] Zhang, H. G., Luo, D. G., Chen, Y. H., et al. Study on start-up of Sulfate-reducing bioreactor using acid wastewater containing thallium. Environmental science \& technology, Vol.33, No.12F, 2010, pp. 207-210.

[6] Su, B. Q., \& Li, Y. X., Formation conditions of anaerobic granular sludge consisted of sulfate reducing bacteria. Environmental protection of chemical industry, Vol.26, No.1, 2006, pp. 26-30.

[7] Li, J. Y., Huang, W. B., Wang, X. L., et al. Research on screening and physiological. Journal of Anhui Agri. Sci., Vol.38, No.29, 2010, pp. 16092-16093.

[8] Hu, K. G., Wang, A. H., Feng, Z. G., et al. Sulfate reducing bacteria and their roles in treatment of sulfate containing waste water. Uranium mining and metallurgy, Vol.26, No.1, 2007, pp. 48-52.

[9] Nie, X. L., Li, H. X., Guo, Z. Y.. Application of sulfate reducing bacteria in wastewater treatment. Journal of Hebei Agricultural Sciences, Vol.13, No.5, 2009, pp. 62-64.

[10] [10] H. T. Q. Kieu, E. Muller, H. Horn. Heavy metal removal in anaerobic semi-continuous stirred tank reactors by a consortium of sulfate-reducing bacteria. Water Research, No.45, 2011, pp.3863-3870.

[11] [11] F. Pagnanelli, C. Cruz Viggi, A. Cibati, et al. Biotreatment of $\mathrm{Cr}(\mathrm{VI})$ contaminated waters by sulphate reducing bacteria fed with ethanol. Journal of Hazardous Materials, Vol.199-120, 2012, pp. 186-192.

[12] Xie, Y. F., Li, X. D., Li, F. D.. Application of biological iron sulfide composites in chromium-containing wastewater treatment and chromium reclamation. China Environmental Science, Vol.29, No.12, 2009, pp. 1260-1265.

[13] R. Singh, A. Kumar, A. Kirrolia, et al. Removal of sulphate, COD and $\mathrm{Cr}(\mathrm{VI})$ in simulated and real wastewater by sulphate reducing bacteria enrichment in small bioreactor and FTIR study. Bioresource Technology, Vol.102, 2011, pp.677-682.

[14] Wang, X. F., Xiang, W. Y., \& Yang, J., Experiment on treating the heavy $\mathrm{Cr}$ ion wastewater by sulfate-reducing bacteria. Journal of water resources \& water engineering, Vol.23, No.2, 2012, pp. 169-171.

[15] Xia, J., Qu, J. G., Ma, J. M., et al. Microbiological treatment technology for wastewater containing zinc. Environmental protection of chemical industry, Vol.25, No.3, 2005, pp.191-194.

[16] Fang, Y., Min, X. B., Tang, N., et al. Research development on the treatment for wastewater containing zinc. Industrial Safety and Environmental Protection, Vol.32, No.7, 2006, pp. 5-8.

[17] Ma Xiaohang, Hua Raoxi, Ye Xueming. Treatment of Zn2+ contaminated wastewater with a method of sulfate bio-reduction. Environmental Science, 1995, 16(4):19-21.

[18] Xia, J., Qu, J. G., Li, F. D.. The basic research of using microorganisms to remove zinc from waste water. Shanghai Chemical Industry, Vol.31, No.8, 2006, pp.1-3.

[19] Chang, X. L., Kang, \& Y., Feng, Y., Treatment of acid zinc wastewater by sulfate reducing bacteria cooperated with iron.The Chinese Journal of Nonferrous Metals, Vol.16,No.9, 2006, pp. 1647-1652.

[20] S. Azabou, T. Mechichi, S. Sayadi. Zinc precipitation by heavy-metal tolerant sulfate-reducing bacteria enriched on phosphogypsum as a sulfate source. Minerals Engineering, Vol.20, 2007, pp.173-178. 
[21] Li, S. J., Chen, T. H., Zhou, Y. F., et al. Effect of Zn ( II ) on microbial activity in anaerobic acid mine drainage treatment system with biomass as carbon source. Environmental Science, Vol.33, No.1, 2012, pp. 293-298.

[22] Zhou Quanyu, Tan Kaixuan, Zeng Sheng, et al. Synergetic treatment of uranium-bearing wastewater with sulfate reducing bacteria and zero-valent iron. Atomic Energy Science and Technology, 2009, 43(9):808-812.

[23] Xie, S. B., Liu, Y. L., Ling, H., et al. Influence of $\mathrm{Cu} 2+$ to sulfate reducing bacteria on removing U(VI). Progress Report on China Nuclear Science \& Technology, Vol.2, 2011, pp. 56-63.

[24] Duan, X. H., \& Li, H.. Treating wastewater from acid in-situ leach uranium mines by SRB. Uranium Mining and Metallurgy, Vol.27, No.3, 2008, pp. 146-149.

[25] Wang, Q. L., Ding, D. X., Zhang, G. Q., et al. Experimental study on condition of manage polluted groundwater in an in-situ leaching uranium mine by using SRB. Morden Mining, Vol.492, 2010, pp.71-73.

[26] Liu Yuelin, Xie Shuibo. Faciors influencing reduction of U (VI) by sulfate reducing bacteria. Uranium Mining and Metallurgy, 2010, 29(4):192-195.

[27] Li, B., Liu, S. P.. The technologies for treating wastewater containing copper and research progress. Multipurpose Utilization of Mineral Resources. Vol.5, 2008, pp. 33-37.

[28] K. Jalali, \& S. A. Baldwin. The role of sulphate reducing bacteria in copper removal from aqueous sulphate solutions. Wat. Res.Vol.34, No.3, 2000, pp.797-806.
[29] Peng, Y. P.. Research of biological acidic mineral wastewater containing copper treatment. Jiang Xi: Mineral Processing Engineering of Jiangxi University, 2008, pp. 1-54.

[30] Zhang, X. Y., \& Li, K. L.. Study on treatment of electroplating waste-water with immobilized SRB. Fine Chemical Intermediates, Vol.39, No.6, 2009, pp. 47-49.

[31] Xu, Y. L.. Study on the treatment of copper wastewater by sulfate reducing bacteria granular sludge in anaerobic baffled reactor. Guangzhou: Environmental Engineering of South China of Technology, 2010, pp. 1-83.

[32] B. M. Tebo, \& A. Ya. Obraztsova. Sulfate-reducing bacterium grows with $\mathrm{Cr}$ (VI), U (VI), Mn (IV), and Fe (III) as electron acceptors. FEMS Microbiology Letters, Vol.162, 1998, pp. 193-198.

[33] M. Martins, M. L. Faleiro, R. J. Barros, et al. Characterization and activity studies of highly heavy metal resistant sulphate-reducing bacteria to be used in acid mine drainage decontamination. Journal of Hazardous Materials, Vol.166, 2009, pp.706-713.

[34] Cao, J. Y., Zhang, G. J., Mao, Z. S., et al. Influence of Mg2+ on the growth and activity of sulfate reducing bacteria. Hydrometallurgy, Vol.95, 2009, pp. 127-134.

[35] C. C. Viggi, F. Pagnanelli, A. Cibati, et al. Biotreatment and bioassessment of heavy metal removal by sulphate reducing bacteria in fixed bed reactors. Water Research, Vol.44, 2010, pp. 151-158.

[36] Niu, X. L., Zheng, J., Li, Q., et al. Experiment of isolation of a sulfate reducing bacteria and treatment of iron manganese wastewater Journal of Water Resources \& Water Engineering, Vol.23, No.2, 2012, pp. 90-92. 